\title{
Internalization Of Understanding Of Poor People Reproductive Health (Case Study In Mangasa Village Tamalate Subdistrict In The City Of Makassar)
}

\author{
Nurul Fitri Sugiarti Syam ${ }^{1}$, Ilcham Syarief Kasim \\ ${ }^{I}$ Department of Midwifery, Universitas Mega Rezky Makassar, Indonesia \\ ${ }^{2,3}$ Department Keperawatan Komunitas Universitas Mega Rezky Makassar, Indonesia
}

Corresponding author: Nurul Fitri Sugiarti Syam

Email: Nurulfitri@gmail.com

\begin{abstract}
Lack of public awareness of the importance of education makes many families caught in the vicious cycle of poverty which will ultimately affect the health sector, especially health reproduction. This research aimed to find out the depth information on the Internalisation of Understanding of Poor People Reproduction Health. This study uses a qualitative design with the research type of case study. The informants of this study are key informants (Health Officers), ordinary (the poor people), and the supporters (head of RW, Health Cadre). The data collection was conducted through observation, interview, and documentation. The data were then analyzed by triangulation analysis. The results showed that there is still a lack of knowledge on reproductive health in most of the poor people due to ineffective socialization activities conducted by parties related to the poor is still less so that the acceptance of society's poor reproductive health is still very limited. It is suggested that the increase of knowledge on the poor by regularly counseling on the poor by involving the role of parents, family, a community of peers. All poor people should find information on the health workers and people around them. The health workers further improve program promotion and education through reproductive health education.
\end{abstract}

\section{Keyword : Poor People, Reproductive Health, Internalization}




\section{PENDAHULUAN}

Hak untuk hidup sehat adalah salah satu bagian dari hak asasi manusia yang merupakan hak dasar semua orang tanpa terkecuali. Kesehatan setiap warga dalam konteks kenegaraan dikelola oleh pemerintah dalam hal ini Kementerian Kesehatan. Pemerintah berkewajiban memerhatikan dan menjalankan amanat Undang-undang Republik Indonesia Nomor 36 Tahun 2009 mengenai kesehatan, tanpa melihat background kepemilikan materi setiap orang. Yang kaya dan yang miskin memiliki kesamaan hak dalam memeroleh perawatan dan akses terhadap kesehatan.

Salah satu bagian dari Kesehatan secara umum adalah Kesehatan Reproduksi. Kesehatan reproduksi berhubungan dengan sistem, fungsi dan proses reproduksi yang mencakup kumpulan metode, teknik dan pelayanan kesehatan reproduksi, kesehatan seksual, hubungan antarpribadi, serta konseling dan perawatan kesehatan reproduksi maupun penyakit menular. Dalam hal Kesehatan Reproduksi, pemerintah telah menerbitkan Kebijakan dan Strategi Nasional Kesehatan Reproduksi pada tahun 2005 silam. Sehubungan dengan hal tersebut, Kementerian Kesehatan beserta seluruh perangkat terkait telah menyelenggarakan sosialisasi serta advokasi Kesehatan Reproduksi yang menyasar semua kalangan. Diharapkan, sosialisasi serta advokasi ini dapat diketahui seluruh lapisan masyarakat. Masyarakat yang mapan secara ekonomi diasumsikan dapat segera memeroleh pengetahuan dan sosialisasi kesehatan tersebut karena akses yang luas serta pola pikir yang cenderung moderat. Sementara itu, masyarakat miskin menjadi menarik untuk dikaji karena masyarakat golongan ini diasumsikan tidak memiliki akses yang baik terhadap promosi kesehatan dikarenakan sarana yang tidak memadai, pola pikir tertutup jika berhadapan dengan hal baru, tingkat pendidikan yang rendah, serta lingkungan yang tidak mendukung.

Data Dinas Sosial Pemerintah Kota Makassar menyebutkan, penduduk Makassar yang berjumlah 1,743.686 jiwa, sebanyak 71.429 kartu keluarga (KK) dengan 286.513 tercatat warga miskin. (Dinas Sosial Kota Makassar, 2016) Penyebaran penduduk Kota Makassar jika dirinci menurut kecamatan, menunjukkan bahwa penduduk masih terkonsentrasi di wilayah Kecamatan Tamalate, yaitu sebanyak 154.464 atau sekitar 12,14\% dari total penduduk, disusul Kecamatan Rappocini sebanyak 145.090 jiwa (11,40\%). Kecamatan Panakkukang sebanyak 136.555 jiwa (10,73\%), dan yang terendah adalah Kecamatan Ujung Pandang sebanyak 29.064 jiwa (2,28\%) (Badan Pusat Statistik, 2011.) Kemiskinan menjadi salah satu persoalan serius yang dihadapi Kota Makassar, dan juga Pemerintah Provinsi Sulawesi 
Selatan. berdasarkan data BPS 2011, jumlah penduduk miskin di kota Makassar ini mencapai 62.096 jiwa. Jumlah penduduk miskin terbanyak berada di Kecamatan Tamalate dengan 9.267 jiwa. Disusul Kecamatan Tallo 8.158 jiwa, Kecamatan Rappocini 6.409 jiwa, Kecamatan Makassar 6.355 jiwa dan Kecamatan Panakkukang 6.237 jiwa (Badan Pusat Statistik, 2016).

Terkait kondisi kontemporer diatas, persoalan yang mengemuka saat ini adalah apakah masyarakat miskin yang diasumsikan lebih terbatas aksesnya dibandingkan dengan masyarakat golongan menengah ke atas, menginternalisasikan pengetahuan kesehatan reproduksi tersebut ke dalam keseharian ?. Lalu masalah lain yang mengemuka adalah bagaimana metode yang tepat agar informasi mengenai kesehatan reproduksi diterima dan terinternalisasi secara berkualitas ke dalam kehidupan masyarakat miskin ?.

Konteks penelitian ini memuat berbagai permasalahan yang mengemuka seputar pengetahuan kesehatan reproduksi, masyarakat miskin dan internalisasi pengetahuan tersebut dalam keseharian. Data diolah secara kualitatif demi hasil yang lebih tepat untuk menggambarkan internalisasi sebuah pengetahuan yang diperoleh berdasarkan informasi dari masyarakat miskin tentang bagaimana cara mereka mengaplikasikan pengetahuan kesehatan reproduksi dalam keseharian. Adapun fokus penelitian akan lebih menjurus ke hal yang spesifik mengenai bagaimana kualitas internalisasi pengetahuan kesehatan reproduksi masyarakat miskin.

\section{BAHAN DAN METODE}

Penelitian ini menggunakan pendekatan kualitatif yang bertujuan untuk menggali informasi sebanyak-banyaknya mengenai topik penelitian. Menurut Danim (2002:32) berpendapat bahwa penelitian kualitatif adalah pendekatan sistematis dan subjektif yang digunakan untuk menjelaskan pengalaman hidup dan memberikan makna atasnya. Sehingga dapat diambil kesimpulan metode penelitian kualitatif adalah penelitian yang menekankan makna dari objek yang menjadi pengamatan dan lebih memusatkan pada kualitas data tersebut. Dalam paradigma penelitian kualitatif, peneliti berupaya memperoleh pemahaman yang mendalam dan interpretasi makna dari sebuah fenomena (Bogdan dan Taylor dalam Moleong, 2000:3). Hasil penelitian kualitatif berupa data deskriptif dalam bentuk kalimat (ucapan/tulisan), atau perilaku teramati. Menurut Maykut dan Morehouse (1994:201), tujuan penelitian kualitatif adalah menemukan pola yang muncul setelah dilakukan pengamatan dari dekat, dokumentasi yang cermat, dan analisis yang teliti. Hasil yang diharapkan dari penelitian ini bukanlah generalisasi hasil, melainkan pemahaman mendalam tentang objek 
penelitian berdasarkan pengalaman dan perspektif informan. Sedangkan jenis penelitian ini yaitu studi kasus, hal ini dimaksudkan agar penelitian berfokus ke kasus secara khusus dan rinci. Sejalan dengan pengertian dari Surachmad (1982) yang berpendapat bahwa studi kasus adalah pendekatan dengan memusatkan perhatian pada suatu kasus secara intensif dan rinci. Lebih lanjut, tujuan dari penelitian kasus ini adalah untuk mempelajari secara intensif tentang latar keadaan kesehatan kontemporer, dan interaksi lingkungan unit sosial, dalam hal ini antara individu miskin, kelompok masyarakat, lembaga kesehatan, dalam kaitannya dengan kebijakan nasional kesehatan reproduksi.

\section{HASIL DAN PEMBAHASAN}

Hasil penelitian dapat menunjukkan bahwa internalisasi pemahaman kesehatan reproduksi yang diperoleh dari sosialisasi melalui kegiatan penyuluhan kesehatan yang dilakukan oleh pihak terkait pada masyarakat miskin masih kurang. Hal ini nampak pada remaja yang berperilaku negatif seperti merokok sehingga dapat menganggu kesehatan reproduksinya dan hanya mengerti bahwa menjaga kebersihan organ intim akan menghindarkannya dari penyakit-penyakit tanpa memperhatikan cara bergaul atau berteman. Pemahaman orang tua akan kesehatan reproduksi tidak hanya sekedar dipahami tetapi dianjurkan untuk dipraktekkan dalam keseharian masyarakat miskin. Pada kenyataannya dilapangan nampak pada masyarakat miskin melakukan menurut kebiasaannya sehari-hari yang hanya sekedar memperhatikan menjaga kebersihan alat reproduksi dan menghiraukan perilaku dalam kesehariannya.Ditambah lagi orang tua mereka yang bersikap acuh tak acuh kepada anaknya terutama mengenai kesehatan reproduksinya dengan alasan menganggap anaknya sudah besar atau sudah mengetahui mana hal yang baik ataupun tidak baik.

Karena kurang informasi yang diperoleh para orang tua dan anak remaja sehingga mereka menganggap semuanya biasa saja.Orangtua sendir terkadangi, baik karena ketidaktahuannya maupun karena sikapnya yang masih mentabukan pembicaraan mengenai organ intim ataupun seks dengan anak, menjadikan mereka tidak terbuka pada anak, bahkan cenderung membuatjarak dengan anak dalam masalah ini. Dari hasil penelitian saat para remaja memasuki masa pubertas atau saat mereka mendapatkan mestruasi/haid pada anak perempuan dan mengalami mimpi basah pada anak laki-laki mereka menanggapinya dengan cara yang berbeda-beda dan reaksi yang berbeda pula. Seperti ada yang menanggapi ketika mengalami hal tersebut dengan santai dan adapula yang ketakutan.Tetapi sebagian besar para remaja 
dengan sigap untuk mengatasi hal tersebut dengan segera membeli pembalut dan menggunakannya.

Kemudian dari hasil penelitian saat orang tua dan anak remaja pada masyarakat miskin dihadapkan pada apa yang mereka lakukan pada saat merasakan sakit dibagian reproduksi atau bagaimana cara mereka mengatasi hal tersebut hanya dengan cara beristirahat atau berbaring, meminum air panas ataupun obat dan adapula yang mengabaikan rasa sakit tersebut karena menganggap rasa sakit pada saat menstruasi adalah hal yang biasa. Sementara penyakit pada system reproduksi manusia dapat disebabkan oleh virus ataupun bakteri.Penyakit yang menyerang system reproduksi manusia biasa juga disebut dengan penyakit kelamin.Pada umumnya, penyakit kelamin ditularkan melalui hubngan seksual dan penyakit tersebut dapat menyerang pria maupun wanita, tua ataupun muda.

Berdasarkan hasil penelitian di atas dapat mencerminkan bahwa internalisasi pemahaman kesehatan reproduksi yang diperoleh dari sosialisasi melalui kegiatan penyuluhan kesehatan yang dilakukan oleh pihak terkait pada masyarakat miskin masih kurang.Hal ini nampak pada remaja yang berperilaku negatif seperti pergaulan bebas sehingga dapat menganggu kesehatan reproduksinya, ditambahkan lagi oleh orang tua mereka yang bersikap acuh tak acuh kepada anaknya terutama mengenai kesehatan reproduksinya dengan alasan menganggap anaknya sudah besar atau sudah mengetahui mana hal yang baik ataupun tidak baik.Cara orang tua dalam mengasuh dan mengontrol tumbuh kembang anak pun hanya terbatas pada memberikan perhatian dan selalu mengingatkan anak remajanya. Sehingga dari hasil peneltian dapat diberikan pandangan bahwa internalisasi antara pengetahuan dan prakteknya dilapangan perlu ditingkatkan mulai dari pengetahuan orang tua dan lebih penting lagi remaja mengenai kesehatan reproduksinya sehingga terhindar dari gangguan penyakit menular.

Dengan memberikan pendekatan yang diterapkan dalam menguraikan ruang lingkup kesehatan reproduksi yaitu pendekatan siklus hidup, yang berarti memperhatikan kekhususan kebutuhan penanganan sistem reproduksi pada setiap fase kehidupan, serta berkesinambungan antar-fase kehidupan tersebut.Dengan demikian, masalah kesehatan reproduksi pada setiap fase kehidupan dapat diperkirakan, yang bila tak ditangani dengan baik maka hal ini dapat berakibat buruk pada masa kehidupan selanjutnya. Sementara proses internalisasi adalah proses yang berlangsung sepanjang hidup individu, yaitu mulai saaat ia dilahirkan sampai akhir hayatnya. Sepanjang hayatnya seorang individu terus belajar untuk mengolah segala perasaan, hasrat, nafsu dan emosi yang membentuk kepribadiannya. Proses menanamkan dan 
menumbuhkembangkan suatu nilai atau budaya menjadi bagian diri orang yang bersangkutan. Kemudian dapat memperoleh aturan-aturan tersebut melelui sebuah komunikasi, seperti sebuah sosialisasi dan pendidikan. Dalam proses internalisasi pola-pola budaya ditanamkan kedalam system syaraf mereka yang kemudian di bentuk menjadi sebuah kepribadian.

\section{KESIMPULAN DAN SARAN}

Kesimpulan dari penelitian ini adalah Pengetahuan kesehatan reproduksi yang dimiliki oleh masyarakat miskin masih terbatas pada menjaga kebersihan bagian reproduksinya saja, Penerimaan masyarakat miskin terhadap pengetahuan seputar kesehatan reproduksi masih kurang, disebabkan kegiatan sosialisasi yang diadakan tidak efektif,dan informasi dari kunjungan langsung door to door yang dilakukan oleh kader kesehatan kurang dimengerti oleh masyarakat miskin. Pengetahuan kesehatan reproduksi pada masyarakat miskin yang diperoleh dari sosialisasi maupun kegiatan penyuluhan kesehatan yang dilakukan oleh pihak terkait, tidak terinternalisasi.

\section{DAFTAR PUSTAKA}

Aaro, L.E. 1997. Adolescent Lifestyle. Dalam A. Baum, S. Newman J. Weinman,R. west and C. McManus (eds) Cambridge Handbook of Psychology, health and Medicine. Cambridge University Press, Cambridge.

Ala, BA.1996. Kemiskinan dan Startegi Memerangi Kemiskinan. Yogyakarta: liberti Badan Pusat Statistik, 2011.

Bahri, Syaiful. 2008. Pemberdayaan Masyarakat Miskin. Tesis. Universitas Airlangga. Surabaya.Depdikbud, 1994

Faturochman. 1992. Sikap dan Perilaku Seks Remaja di Bali, Jurnal Psikologi no.1.

Gunarsa, Singgih, D dan Yulia Singgih D. Gunarsa.1991, Psikologi praktis: Anak, Remaja dan Keluarga, Gunung Mulia, Jakarta, cet. Ke-1

Hadiyanti, Puji. 2006. Kemiskinan dan Upaya Pemberdayaan Masyarakat. Tersedia: Jurnal Pengembangan Masyarakat Islam

Hurlock, E.B. 1990. Developmental Psychology : A lifespan Approach. Boston: McGrawHill.

International Conference on Population and Development (ICPD) tahun 1994

Kartono Mohamad. dalam Diskusi Panel Islam Dan Pendidikan Seks Bagi Remaja, 1991. 
Kamus Besar Bahasa Indonesia. 2016. daring (diakses tanggal 15 Agustus 2016 Pukul 18.00) Kebijakan dan Strategi Nasional Kesehatan Reproduksi di Indonesia, 2005.

Kuncoro Mudrajad, 2002. Metode Riset Untuk Bisnis dan Ekonomi. Jakarta : Erlangga.

Lumongga, L. Namora. 2013. Psikologi Kespro. Kencana Prenada Media

Moleong Lexy J. 2004, Metodologi Penelitian Kualitatif, Bandung: Remaja Rosdakarya.

Manuaba. Dkk. 2009. Memahami Kesehatan Reproduksi Wanita. Jakarta: EGC.

Nana Sudjana. 1995. Penilaian Hasil Proses Belajar Mengajar. Bandung: PT Remaja Rosdakarya

Nasikun. 1995. Kemiskinan di Indonesia Menurun Dalam Perangkap Kemiskinan dan Strategi Pengentasannya. Tersedia

Notoadmodjo. 2012. Metodologi Penelitian Kesehatan. Jakarta: Rineka Cipta. . 2014.Ilmu Kesehatan Masyarakat, Jakarta: PT Rineka Cipta.

Nurhadi. 2007. Mengembangkan Jaminan Sosial Mengentaskan Kemiskinan, cetakan pertama. Yogyakarta : Media Wacana

Papalia, D.E., Olds, S.W., \& Feldman, Ruth D. (2001) Human Development $\left(8^{\text {th }}\right.$ ed): Boston: McGraw-Hill

Prasetyawati, Arsita Eka. 2012. Kesehatan Ibu dan Anak (KIA) dalam Millenium Development Goals (MDG'S). Yogyakarta : Nuha Medika

Pusat Studi Kependudukan dan Kebijakan, Universitas Gajah Mada, 2010

Rice,F.P. 2001. The Adolescent Development, Relationship \& Culture. Boston. Ally \& Bacon.

Rochmawati, Lusa, 2011. Menentukan usia kehamilan. Yogyakarta dan Surakarta.

Sajogyo, P. 1987. Pengembangan Peranan Wanita Khususnya di Pedesaan Yang Sedang Berubah dari Masyarakat Pertanian ke Industri di Indonesia 1981-1987. Seminar Fungsi Sosial Ekonomi Wanita Indonesia.

Sarwono, Sarlito W. 2010. Psikologi Remaja. Jakarta. Rajawali Persada

Situmorang, C. 2009. Penanganan Masalah Kemiskinan di Sumatera Utara

Sugiyono, 2008. Memahami Penelitian Kualitatif. Jakarta. Alfabeta

Suharto, Edi. 2009. Kemiskinan dan Perlindungan Sosial di Indonesia. Bandung : Alfabeta 
Sumartini, Titik. 2007. Jurnal Transdisiplin Sosiologi, Komunikasi, dan Ekologi Manusia. Bandung : IPB

Suryawaty, Chriswardani. 2005. Memahami Kemiskinan Secara Multidimensional, Fakultas Kesehatan Masyarakat dan Magister Ilmu Kesehatan Masyarakat Jurnal Pembangunan. Universitas Diponegoro. Semarang. Jawa Tengah

Sutyastie Remi dan P. Tjiptoherijanto. 2002. Kemiskinan dan Ketidakmerataan di Indonesia. Sinar Grafika : Jakarta

Tambunan, Tulus. 2001. Perkembangan Sektor Pertanian di Indonesia (Beberapa Isu Penting). Jakarta : Ghalia Indonesia

Tirto, Husodo. 1987. Seksualitet dalam mengenal dunia Remaja. Bandung: Alfabeta

UNHAS, 1992. Metode Penelitian Ilmu Sosial. Ujung Pandang

World Health Organitation (WHO). 2009. 